\begin{tabular}{c} 
SUR Y A A B D I M A S \\
Vol. 5 No. 3 (2021) pp. $312-321$ \\
Aveailable online at: $\underline{\text { http://jurnal.umpwr.ac.id/index.php/abdimas/index }}$ \\
p-ISSN: $\underline{2580-3492}$ e-ISSN: $2581-0162$ \\
\hline
\end{tabular}

\title{
Penguatan Pemahaman Masyarakat Terhadap Keterbukaan Informasi Publik
}

\section{Bayu Indra Pratama $\bowtie$, Dessanti Putri Sekti Ari}

\section{Universitas Brawijaya}

Jl. Mayjen Haryono 169, Lowokwaru - Jl. Veteran, Malang 65145, Jawa Timur, Indonesia | bayuindrap@ub.ac.id $₫ \mid$ DOI : https://doi.org/10.37729/abdimas.v5i3.1281 |

\footnotetext{
Abstrak

Undang-undang Nomor 14 tahun 2008 tentang Keterbukaan Informasi Publik memberikan jaminan hak memperoleh informasi publik. Warga negara sebagai pembayar pajak berhak tahu segenap pelaksanaan pelayanan publik yang dibiayai oleh pajak. Keterbukaan informasi juga merupakan pondasi penting dalam demokrasi. Pemikiran ini mendorong upaya berkelanjutan untuk semangat keterbukaan publik melalui penyelenggaraan webinar penguatan pemahaman masyarakat terhadap keterbukaan informasi publik. Tujuan kegiatan tersebut untuk meningkatkan pemahaman masyarakat terhadap keterbukaan informasi publik. Acara ini diselenggarakan pada tanggal 27 Juli 2020 pada pukul 09.00 sampai dengan 11.00 WIB. Berdasarkan evaluasi webinar yang telah dilakukan terjadi peningkatan pemahaman tentang keterbukaan informasi publik. Materi yang disampaikan telah sesuai dengan kebutuhan peserta terkait terma tersebut. Sosialisasi keterbukaan informasi publik perlu dilakukan secara lebih massif untuk mendorong partisipasi masyarakat dalam demokrasi serta mendukung tata kelola pemerintahan yang baik.

Kata Kunci: Webminar, Pemahaman masyarakat, Keterbukaan informasi, Publik

(c) (7) (5) This work is licensed under a Creative Commons Attribution-NonCommercial 4.0
International License
}

\section{Pendahuluan}

Keterbukaan informasi merupakan prasyarat penting dalam tata kelola pemerintahan yang baik (good governace) (Retnowati, 2012). Kemampuan publik mengakses informasi publik menjamin transparansi dan akuntabilitas layanan publik. Hal ini didasari pemikiran bahwa layanan publik biayai oleh pajak (Revida et al., 2021). Warga negara sebagai pembayar pajak berhak tahu segenap pelaksanaan pelayanan publik yang dibiayai oleh pajak. Keterbukaan informasi juga merupakan pondasi penting dalam demokrasi (Rifai, 2008b; Setiaman, Sugiana, \& Mahameruaji, 2013). Transparansi dan akuntabilitas yang dapat diakses publik memungkinkan kehadiran kontrol politik terhadap pelaksanaan kehidupan bernegara oleh warga negara. Tentu bukan dalam semangat untuk menjatuhkan atau menganggu roda pemerintahan. Akses informasi memungkinkan warga negara mengawasi serta aktor politik menyadari bahwa ia bertanggung jawab kepada rakyat (Rifai, 2008b; Setiaman et al., 2013).

Jaminan terhadap keterbukaan informasi publik secara fundamental tertuang dalam pasal 28F Undang-undang Dasar Negara Republik Indonesia 1945. Pasal tersebut menjadi landasaan atau dasar bahwa warga negara berhak secara bebas untuk memperoleh informasi. Kebebasan ini tidak bersifat mutlak karena pasal 28J Undangundang Dasar Negara Republik Indonesia mensyaratkan hak azasi manusia hak dan 
kebebasannya, setiap orang wajib tunduk kepada pembatasan yang ditetapkan dengan undang-undang dengan maksud semata-mata untuk menjamin pengakuan serta penghormatan atas hak dan kebebasan orang lain dan untuk memenuhi tuntutan yang adil sesuai dengan pertimbangan moral, nilai-nilai agama, keamanan, dan ketertiban umum dalam suatu masyarakat demokratis. Pengaturan terhadap pelaksanaan keterbukaan informasi publik kemudian diatur dalam Undang-undang Nomor 14 tahun 2008 tentang Keterbukaan Informasi Publik.

Undang-undang tersebut secara evolutif mendorong badan publik menjadi lebih terbuka sehingga informasinya dapat diakses oleh publik (Suryani \& Saharuddin, 2021). Hal ini mendorong perbaikan manajemen serta tata kelola informasi pada badan-badan publik (Febriananingsih, 2012). Situasi ini berbeda jika dibandingkan dengan Orde Baru yang cenderung menganggap segenap informasi badan publik bersifat rahasia serta terbatas. Undang-undang tersebut kini memberikan kebebasan masayarakat untuk mengakses informasi secara terbuka dengan pengecualian yang telah ditentukan (Saputra, 2019).

Perbedaan pemahaman antara pemohon informasi publik dan badan publik yang bertanggung jawab terhadap informasi kerap menimbulkan sengketa informasi. Pemohon tetap ingin memperoleh informasi yang dinilai dibutuhkannya. Pada sisi lain, badan publik terkadang enggan atau merasa tidak perlu memberikannya. Sengketa informasi ini kemudian harus diselesaikan oleh Komisi Informasi Publik. Lembaga ini telah bertugas menyelesaikan informasi publik sejak tahun 2010. Jumlah permohonan dan penyelesaian sengketa informasi publik yang diolah dari Laporan Kinerja Komisi Informasi Publik tahun 2019 tersaji dalam Tabel 1.

Tabel 1. Jumlah permohonan dan penyelesaian sengketa informasi publik

\begin{tabular}{ccc}
\hline Tahun & Permohonan & Penyelesaian \\
\hline 2010 & 76 & 51 \\
2011 & 419 & 186 \\
2012 & 324 & 286 \\
2013 & 377 & 125 \\
2014 & 1354 & 123 \\
2015 & 71 & 94 \\
2016 & 64 & 54 \\
2017 & 120 & 32 \\
2018 & 60 & 1280 \\
2019 & 63 & 350 \\
\hline
\end{tabular}

Berdasarkan data tersebut maka dapat ditinjau beberapa hal. Pertama, terjadi tren peningkatan penyelesaian sengketaan informasi publlik setiap tahun. Kedua, terjadi tren penurunan permohonan sengketa informasi. Data tersebut kemudian dapat dimaknai bahwa semakin minim sengketa informasi publik karena kemampuan badan publik menangani permohonan informasi semakin baik. Pada sisi lain, penurunan permohonan sengketa informasi dapat disebabkan pemahaman masyarakat terhadap informasi publik yang menurun. Terlepas kedua tafsir tersebut, upaya untuk menjaga semangat keterbukaan informasi publik perlu dipertahankan demi akutabilitas serta transparansi tata kelola pemerintahan serta demokrasi. 
Pemikiran ini yang kemudian mendorong tim pengabdian masyarakat dari Fakultas Ilmu Administrasi Universitas Brawijaya untuk melakukan webinar penguatan pemahaman masyarakat terhadap keterbukaan informasi publik. Kegiatan tersebut bertujuan untuk meningkatkan pemahaman masyarakat terhadap keterbukaan informasi publik. Subjek sasaran kegiatan ini bersifat terbuka untuk umum. Hal ini menyebabkan semua kalangan dan latar belakang dapat mengikuti kegiatan webinar ini. Pembatasan sosial yang menyebabkan penyelenggaraan secara luring sehingga bentuk webinar dipilih sebagai media pengabdian kepada masyarakat. Penggunaan webinar juga diharapkan mampu menjangkau khalayak yang lebih luas.

\section{Metode}

Diseminasi informasi terkait dengan Keterbukaan Informasi Publik pada masyarakat dilakukan dengan menyelenggarakan Webinar. Kegiatan ini bersifat umum sehingga berbagai kalagan dapat mengikuti kegiatan ini. Webinar tersebut diinisiasi oleh Tim Pengabdian Masyarakat Fakultas Ilmu Administrasi, Universitas Brawijaya. Tujuan kegiatan webinar keterbukaan informasi publik ini untuk meningkatkan pengetahuan serta keterampilan yang diperlukan dalam mengakses informasi publik. Aktivitas ini merupakan inti tahapan acara webinar keterbukaan informasi. Acara ini diselenggarakan pada tanggal 27 Juli 2020 pada pukul 09.00 sampai dengan 11.00 WIB. Aktivitas ini berisikan penyampaian materi dari 3 narasumber dan tanya jawab di akhr sesi materi. Pemateri kegiatan tersebut terdiri dari: Bapak Bayu Indra Pratama (Dosen Ilmu Perpustakaan Fakultas Ilmu Administrasi UB), Bapak Endry Putra (Dosen Ilmu Perpustakaan Fakultas Ilmu Administrasi UB), dan Bapak Feri Firdaus (mantan Staf Ahli Komisi Informasi Publik).

Webinar ini diikuti oleh 92 peserta yang hadir secara daring. Tahapan kegiatan yang dilakukan antara lain sebagai berikut,

a. Registrasi peserta webinar menggunakan Google Form

b. Penyampaian materi oleh tiga narasumber yang antara lain,

1) Bayu Indra Pratama menyampaikan penjelasan tentang pengantar keterbukaan informasi publik.

2) Endry Putra menyampaikan materi demokrasi dan keterbukaan informasi publik

3) Feri Firdaus menyampaikan ketentuan perundang-undangan serta teknis penyelesaian sengketa informasi.

c. Penyebaran kuesoner pengabdian masyarakat.

Kegiatan ini juga berkolaborasi dengan mahasiswa Program Studi Ilmu Perpustakaan Fakultas Ilmu Administrasi Universitas Brawijaya dalam melakukan publikasi serta siaran melalui kanal Youtube Himpunan Mahasiswa Program Studi Ilmu Perpustakaan. 


\section{Hasil dan Pembahasan}

Keterbukaan informasi publik merupakan hal yang esensial dalam demokrasi. Publik berhak mengetahui beragam hal yang telah dilakukan oleh badan publik. Hal ini sebabkan anggaran penyelenggaraan badan publik bersumber dari pajak. Tentu jika dikaitkan dengan pajak, maka ada hal publik yang terkandung dalam setiap kegiatan badan publik (Revida et al., 2021). Berdasarkan undang-undang Undang-undang No 14 tahun 2018 tentang Informasi Publik, Badan Publik adalah Badan Publik adalah lembaga eksekutif, legislatif, yudikatif, dan badan lain yang fungsi dan tugas pokoknya berkaitan dengan penyelenggaraan negara, yang sebagian atau seluruh dananya bersumber dari Anggaran Pendapatan dan Belanja Negara dan/atau Anggaran Pendapatan dan Belanja Daerah, atau organisasi nonpemerintah sepanjang sebagian atau seluruh dananya bersumber dari Anggaran Pendapatan dan Belanja Negara dan/ atau Anggaran Pendapatan dan Belanja Daerah, sumbangan masyarakat, dan/ atau luar negeri.

Definisi tersebut menempatkan berbagai institusi sebagai badan publik. Pada sisi lain, penggunaan hak warga negara untuk memperoleh informasi publik dari badan publik kerap tidak mudah (Prastya, 2017). Hal ini disebabkan ketidaksepahaman antara pemohon informasi publik dengan badan publik. Ketidaksepahaman ini yang kemudian menyebabkan sengketa informasi publik (Fatoni, 2019; Supriatna, 2016). Hal ini menjadikan peningkatan pemahaman masyarakat tentang informasi publik menjadi perlu dilakukan.

Tim pengabdian kepada masyarakat Fakultas Ilmu Administrasi Universitas Brawijaya kemudian mengadakan inisiasi peningkatan kapasitas informasi publik kepada masyarakat. Kegiatan ini diselegarakan secara daring melalui webinar untuk memenuhi protokol kesehatan selama masa pandemi Covid-19. Kegiatan dalam bentk webminar ini dapat ditunjukkan pada Gambar 1.

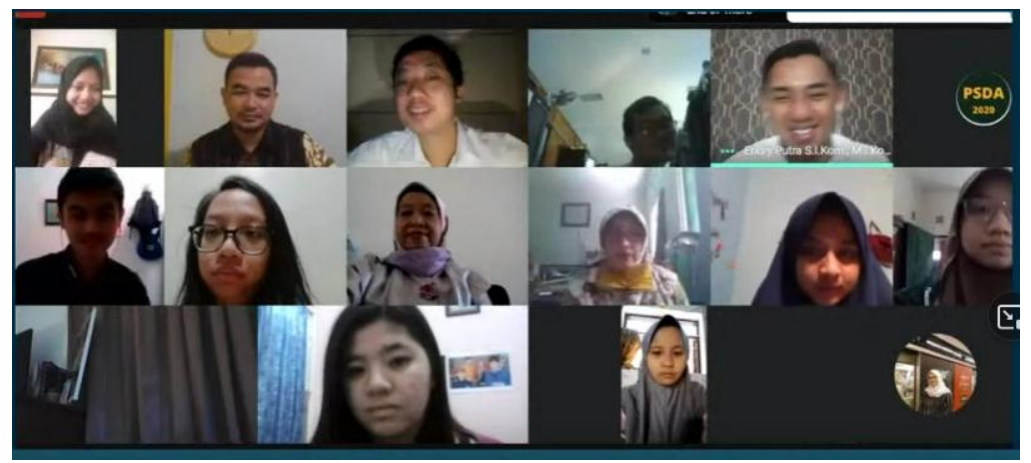

Gambar 1. Webinar keterbukaan informasi publik

\subsection{Kegiatan 1: Materi Aspek Teoritis Keterbukaan Informasi Publik}

Keterbukaan informasi publik merupakan hak warga negara (Prastya, 2017). Logika ini dibangun berdasarkan bahwa layanan publik dibiayai oleh pajak. Warga negara sebagai pembayar pajak berhak mengetahui penggunaan uangnya (Revida et al., 2021). Hal ini berimplikasi pada dorongan untuk membangun sebuah pengaturan terhadap informasi publik. Pengaturan ini perlu karena informasi memiliki sebuah nilai yang dapat dipertukarkan. Tidak semua informasi dapat dibagikan kepada publik. Pada sisi lain, ada hal-hal yang perlu diakses oleh publik. Pengaturan menjadi jalan tengah untuk menghindarkan sengketa informasi sekaligus penguatan terhadap layanan publik itu sendiri (Muhaimin, 2018). 
Pembahasan tentang hak terhadap informasi publik dari ditarik hingga pada konstitusi Undang-undang Dasar Negara Republik Indonesia tahun 1945. Pasal 28F Undang-undang Dasar Negara Republik Indonesia tahun 1945 menyebutkan bahwa, "Setiap orang berhak untuk berkomunikasi dan memperoleh informasi untuk mengembangkan pribadi dan lingkungan sosialnya, serta berhak untuk mencari, memperoleh, memiliki, menyimpan, mengolah dan menyampaikan informasi dengan menggunakan segala jenis saluran yang tersedia". Pasal ini menjadi landas fundamental yang menyatakan bahwa setiap warga negara Undang-undang (UU) No. 14 Tahun 2008 tentang Keterbukaan Informasi Publik. Kedua landasan ini kemudian mengikat seluruh badan publik untuk wajib menyediakan informasi publik. Badan publik menurut undang-undang tersebut didefinisikan sebagai lembaga eksekutif, legislatif, yudikatif, dan badan lain yang fungsi dan tugas pokoknya berkaitan dengan penyelenggaraan negara, yang sebagian atau seluruh dananya bersumber dari Anggaran Pendapatan dan Belanja Negara dan/atau Anggaran Pendapatan dan Belanja Daerah, atau organisasi nonpemerintah sepanjang sebagian atau seluruh dananya bersumber dari Anggaran Pendapatan dan Belanja Negara dan/atau Anggaran Pendapatan dan Belanja Daerah, sumbangan masyarakat, dan/atau luar negeri (UU No.14 Tahun 2008).

Legitimasi ini kemudian menjadi peroleh informasi publik menjadi sebebasbebasnya. Penggunaan hak memperoleh informasi sebagai bagian hak azasi manusia harus tunduk berdasarkan undang-undang yang berlaku. Konstitusi melalui pasal 28J ayat (2) UUD Negara Republik Indonesia 1945 menegaskan bahwa pelaksanaan hak azsi manusia menjamin hak dan kebebasan individu tetapi untuk memenuhi tuntutan yang adil sesuai dengan pertimbangan moral, nilai -nilai agama, keamanan, dan ketertiban umum dalam suatu masyarakat. Pasal 6 Undang-undang No. 14 tahun 2008 memberikan pengecualian pada informasi: (i) informasi yang dapat membahayakan negara; (ii) informasi yang berkaitan dengan kepentingan perlindungan usaha dari persaingan usaha tidak sehat; (iii) informasi yang berkaitan dengan hak-hak pribadi; (iv) informasi yang berkaitan dengan rahasia jabatan; dan/atau; (v) Informasi Publik yang diminta belum dikuasai atau didokumentasikan.

Pengantar materi tentang keterbukaan publik disampaikan oleh Bapak Bayu Indra Pratama, seperti disajikan pada Gambar 2.

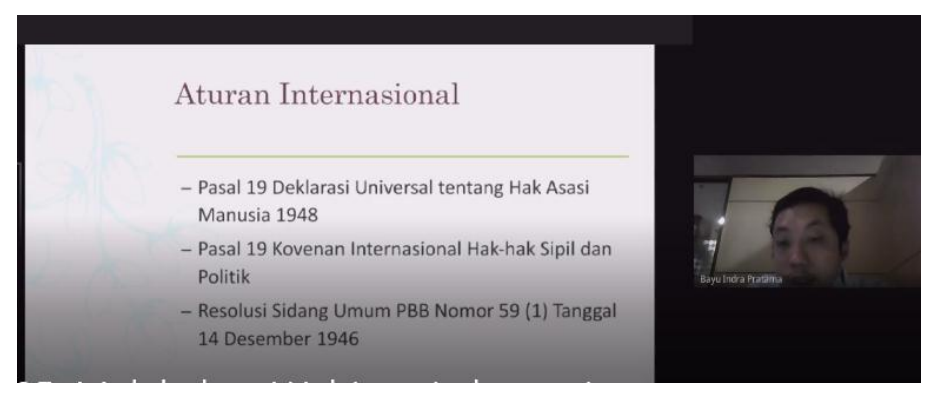

Gambar 2. Penyampaian materi tentang pengantar keterbukaan informasi publik

\subsection{Kegiatan 2: Demokrasi dan Keterbukaan informasi Publik}

Demokrasi dan keterbukaan informasi publik merupakan dua hal yang saling berdampingan. Demokrasi membutuhkan keterbukaan informasi publik karena hal tersebut merupakan wujud dari transparansi. Ketidaktransparan dalam praktik-praktik pelayanan publik dapat tumbuh dan berkembang sebagai ancaman bagi demokrasi serta tata kelola pemerintahan yang baik (Retnowati, 2012). 
Ketidaktransparan berpotensi menimbulkan abuse of power (Muliawaty \& Hendryawan, 2020), hal ini menafikan hak dari warga negara terhadap pelayanan publik. Padahal pelayanan publik dibiayai oleh warga negara melalui pajak.

Penjagaan terhadap keterbukaan informasi menjadi prasyarat yang tidak boleh ditinggalkan. Refleksi terhadap pengabaian terhadap keterbukaan informasi publik pernah terjadi di masa Orde Baru. Warga negara tidak dapat memperoleh kepastian memperoleh informasi dari lembaga publik (Saputra, 2019). Semua informasi publik cenderung dianggap terbatas serta dapat dikategorikan rahasia. Tentu hal ini berimplikasi terhadap penyalagunaan wewenang oleh penyelenggara layanan publik. Ketiadaan transparansi menyebabkan nir-pengawasan. Korupsi, kolusi, serta nepotisme kemudian menjadi penyakit dalam pelayanan publik.

Penjagaan terhadap ruh transparansi melalui keterbukaan informasi publik perlu terus dijaga. Berbagai layanan yang memungkinkan masyarakat mengakses serta memperoleh informasi perlu dibuka. Tentu pengeculian informasi publik yang telah diamanahkan oleh undang-undang serta konstitusi tetap perlu penjadi landas pikir bersama (Rifai, 2008a). Jika hal yang dikecualikan lebih sedikit, maka warga negara perlu lebih tahu. Tujuan akhir dari keterbukaan informasi publik bukan untuk menganggu layanan publik, melainkan menjadi alat kontrol bagi masyarakat. Pada sisi lain, transparansi yang ada mendorong komitmen menjalankankan layanan publik dengan penuh tanggung jawab (Muhaimin, 2018). Muara dari kedua hal tersebut yakni kerja kolektif untuk mendorong layanan publik yang efektif, efisien, serta bertanggung jawab. Terkait demokrasi dan keterbukaan informasi publik dalam webminar ini dipaparkan oleh Bapak Endry Putra, seperti Gambar 3.

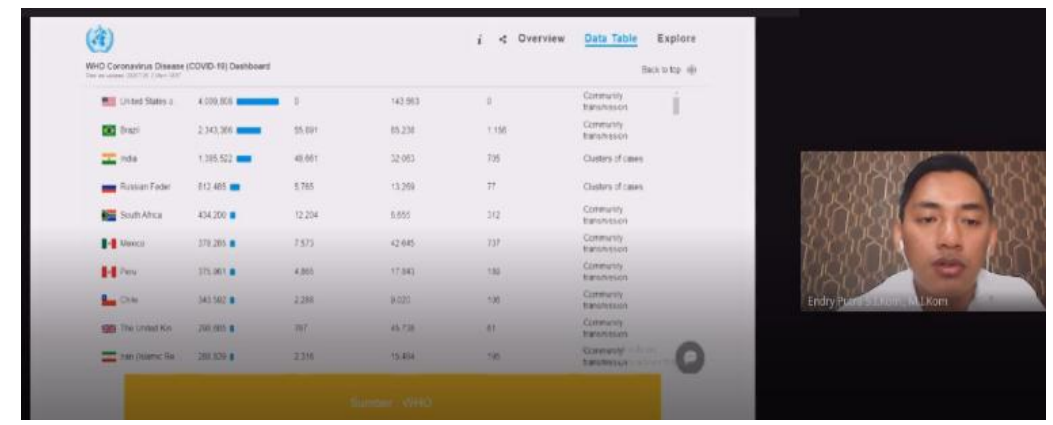

Gambar 3. Penyampaian materi tentang demokrasi dan keterbukaan informasi publik

\subsection{Kegiatan 3: Materi Aspek Teoritis teknis Penyelesaian Sengketa Informasi.}

Upaya untuk memperoleh informasi publik kerap tidak menemui hasil. Badan publik yang bertanggung jawab terhadap informasi publik enggan memberikan informasi. Padahal informasi tersebut tidak termasuk dalam informasi yang dikecualikan dapat diakses oleh publik. Hal ini mengakibatkan sengketa informasi publik. Perlu ada pihak ketiga yang menjadi mediator antara pihak-pihak yang bersengketa (Syam, 2015). Ketika tidak ditemui kata mufakat maka lembaga tersebut harus memutuskan apakah informasi tersebut dapat diakses tersebut. Hal ini merupakan kewenangan komisi informasi publik. Lembaga ini berwenang sebagai mediator sekaligus pemutus perkara sengketa informasi publik. Pemaparan oleh Bapak Feri Firdaus tentang teknis penyelesaian sengketa informasi disajikan pada Gambar 4. 


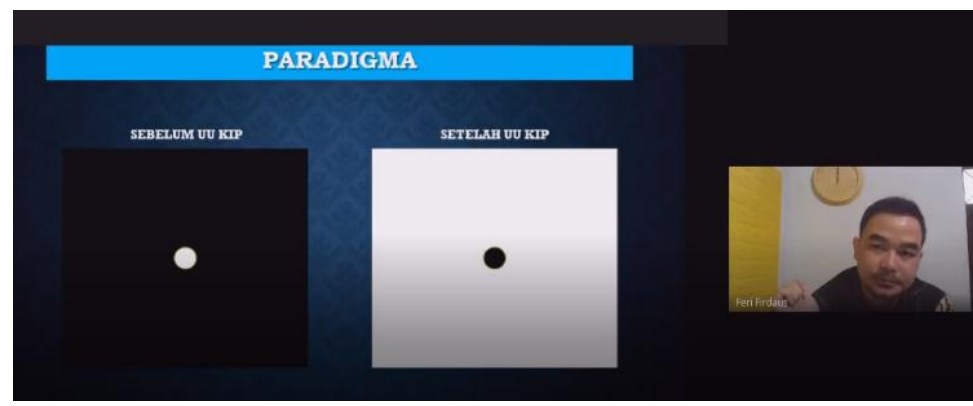

Gambar 4. Penyampaian materi tentang teknis penyelesaian sengketa informasi

Masyarakat perlu mengetahui mekanisme untuk memperoleh informasi publik. Hal ini menjadi kerangka acuan yang relevan sehingga individu yang mengajukan permohonan informasi publik tidak menyalahi prosedur. Ketentuan dasar permohonan informasi publik tertuang dalam Peraturan Komisi Informasi No. 1 Tahun 2010 Tentang Standar Layanan Informasi Publik Tahun 2010. Peraturan ini memberikan standar minimal permohonan informasi publik. Setiap badan publik mungkin saja memiliki perbedaan media penyampaian permohonan namun standar layanan ini telah menjadi aturan baku. Perbedaan tersebut dapat berupa media yang dapat digunakan oleh pemohon seperti surat, e-mail, tatap muka, atau mekanisme yang diberikan oleh badan publik.

Jika berkaitan dengan sengketa informasi, maka peraturan yang digunakan adalah Peraturan Komisi informasi No.2 Tahun 2010 Tentang Prosedur Penyelesaian sengketa. Peraturan ini memuat asas penyelesaian, kewenangan komisi informasi, pengajuan permohonan penyelesaian sengketa sengketa, registrasi permohonan penyelesaian sengketa, pemeriksaan pendahuluan, penetapan mediator, prosedur mediasi, serta prosedur ajudikasi. Aturan-aturan ini dapat dengan mudah dibaca dan dipahami sebagai landasan berpikir serta bertindak dalam sengketa informasi publik.

\subsection{Respon Peserta Kegiatan Pengabdian Kepada Masyarakat}

Pada akhir sesi webinar, tim pengabdian masyarakat mengajukan riset terhadap pemahaman peserta. Tim mengirimkan link kuesioner yang dapat diisi peserta melalui Google Form. Berdasarkan kuesioner yang dibagikan kepada peserta, terkumpul 92 umpan balik dengan hasil seperti pada Gambar 5.

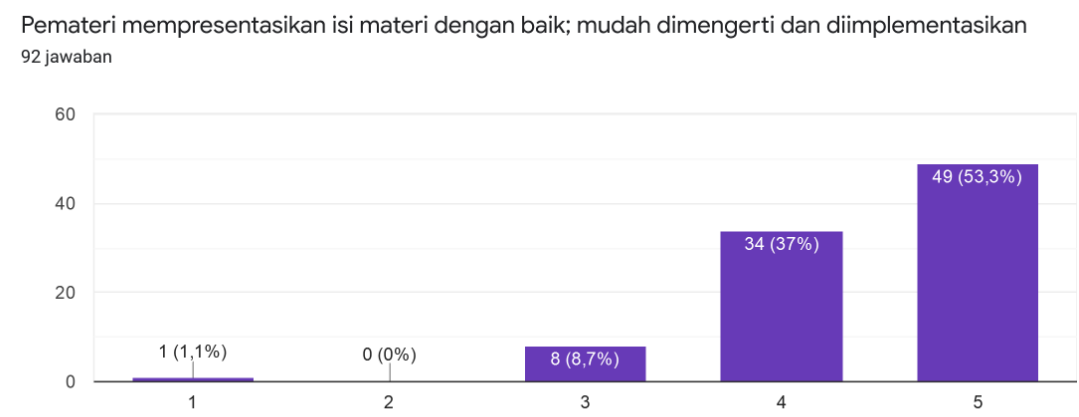

Gambar 5. Hasil kuesioner respon peserta webminar 
Berdasarkan Gambar 5 menunjukan bahwa 49 (53,3\%) peserta sangat puas dan 34 (37\%) peserta puas dengan materi yang disampaikan pada acara ini. Jika diakumulasi maka tingkat kepuasan terhadap pemateri ini mencapai 90,3\%. Hanya 9,7\% peserta secara akumulatif yang merasa tidak puas dan cukup. Selain melalui kuesioner, dalam kegiatan ini dilakukan tanya jawab guna mengetahui tingkat pemahaman peserta, seperti disajikan pada Gambar 6.

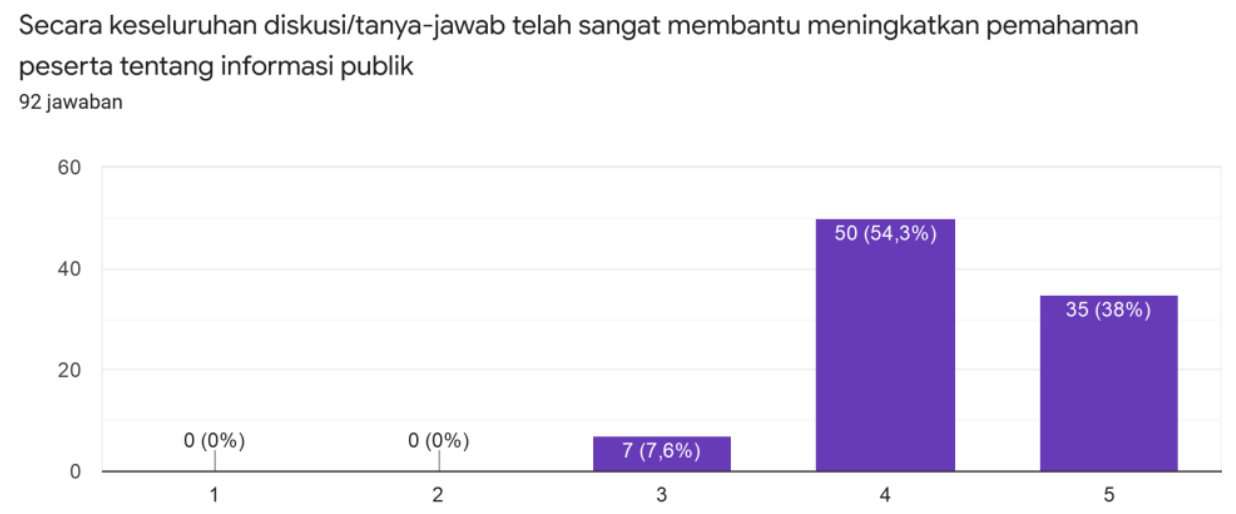

Gambar 6. Hasil diskusi/ tanya jawab pemahaman peserta tentang informasi publik

Berdasarkan Gambar 6 menunjukan bahwa 40 (54,3\%) peserta sangat puas dan 35 (38\%) peserta puas dengan diskusi dalam acara ini. Jika diakumulasi maka tingkat kepuasan terhadap pemateri ini mencapai $92,4 \%$. Hanya $7(7,6) \%$ peserta secara akumulatif yang merasa cukup. Hal ini menunjukan proses diskusi dapat membantu meningkatkan pemahaman peserta tentang informasi publik.

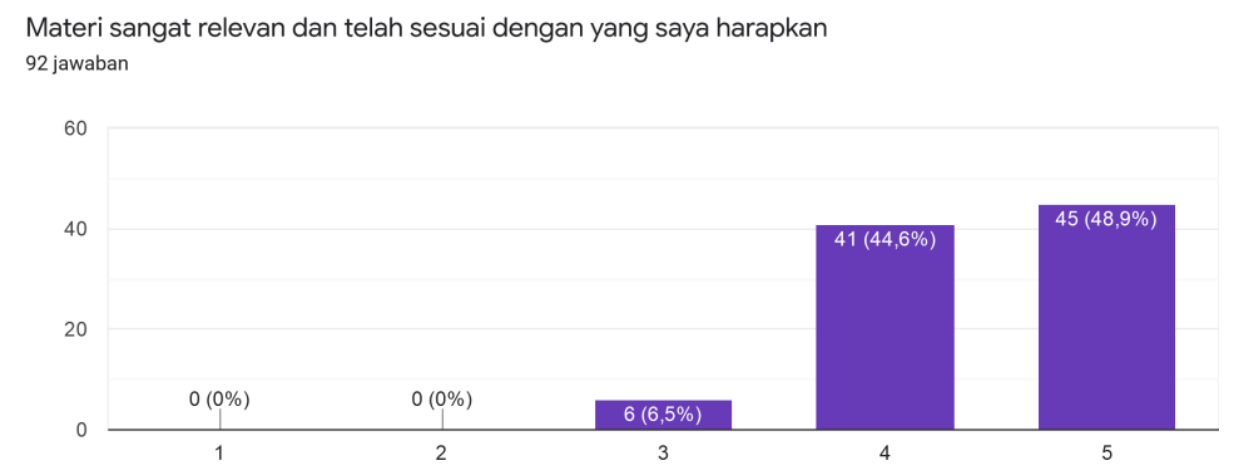

Gambar 7. Hasil kuesioner pertanyaan kesesuaian harapan peserta dan materi yang diperoleh.

Gambar 7 menunjukan bahwa 45 (48,9\%) peserta sangat puas dan $41(44,6 \%)$ peserta puas dengan diskusi dalam acara ini. Jika diakumulasi maka tingkat kepuasan terhadap pemateri ini mencapai $93,5 \%$. Hanya $6(6,5) \%$ peserta secara akumulatif yang merasa cukup. Hal ini menunjukan materi membant meningkatkan pemahaman peserta tentang informasi publik 


\section{Kesimpulan}

Kegiatan webinar berjalan dengan lancar dan sukses. Peserta juga memperoleh peningkatan pemahaman tentang informasi publik. Mereka mengetahui urgensi informasi publik serta tata cara permohonan informasi publik. Jika terjadi sengketa informasi, maka peserta juga mengetahui tata cara penyelesaian sengketa informasi. Berdasarkan kuesioner yang disebarkan juga peserta merasa puas terhadap materi, diskusi, serta penyampaian pemateri selama webinar berlangsung. Hal ini sesuai dengan harapan tim pengabdian masyarakat untuk meningkatkan pemahaman tentang informasi publik.

\section{Acknowledgement}

Tim penulis artikel ini mengucapkan terima kasih kepada Fakultas Ilmu Administrasi, Universitas Brawijaya yang telah mendukung terselenggaranya kegiatan ini. Kami juga menyampaikan ucapan terima kasih kepada Himpunan Mahasiswa Program Studi Ilmu Perpustakaan yang telah berkerjasama dalam menyelenggarakan kegiatan pengabdian kepada masyarakat ini.

\section{Daftar Pustaka}

Fatoni, A. W. (2019). Penyelesaian Sengketa Keterbukaan Informasi Publik Melalui Ajudikasi dalam Undang-Undang Nomor 14 Tahun 2008 tentang Keterbukaan Informasi Publik. Jurnal Ius Constituendum, 4(1), 78-94.

Febriananingsih, N. (2012). Keterbukaan informasi publik dalam pemerintahan terbuka menuju tata pemerintahan yang baik. Jurnal Rechts Vinding: Media Pembinaan Hukum Nasional, 1(1), 135-156.

Muhaimin, M. (2018). Penguatan Penyelenggaraan Pelayanan Publik melalui Penyelesaian Sengketa Informasi Publik. Jurnal Ilmiah Kebijakan Hukum, 12(2), 213-226.

Muliawaty, L., \& Hendryawan, S. (2020). Peranan e-government dalam pelayanan publik (studi kasus: Mal pelayanan publik Kabupaten Sumedang). Kebijakan: Jurnal Ilmu Administrasi, 11(2), 45-57.

Prastya, N. M. (2017). Kendala Struktural dan Kultural Praktek Keterbukaan Informasi Publik di Badan Publik Non-Pemerintah: Studi Kasus PSSI. Jurnal Komunikasi, 9(2), 98-111.

Retnowati, E. (2012). Keterbukaan informasi publik dan good governance (antara das sein dan das sollen). Perspektif, 17(1), 54-61.

Revida, E., Aisyah, S., Pardede, A. F., Purba, S., Hidayatulloh, A. N., Leuwol, N. V., . . . Manullang, S. O. (2021). Manajemen Pelayanan Publik: Yayasan Kita Menulis.

Rifai, A. (2008a). Kemerdekaan informas: Catatan atas Undang-Undang Keterbukaan Informasi Publik. Jurnal Dakwah, 9(2), 101-115. 
Rifai, A. (2008b). KEMERDEKAAN INFORMASI: Catatan atas Undang-Undang Keterbukaan Informasi Publik. Jurnal Dakwah, 9(2), 101-115.

Saputra, W. (2019). Implementasi Undang-Undang Keterbukaan Informasi Publik Dan Transparansi Pelayanan Publik Di Jawa Timur. Al-Adabiya: Jurnal Kebudayaan dan Keagamaan, 14(01), 31-48.

Setiaman, A., Sugiana, D., \& Mahameruaji, J. N. (2013). Implementasi kebijakan keterbukaan informasi publik. Jurnal Kajian Komunikasi, 1(2), 196-205.

Supriatna, K. (2016). Kontra produktif keterbukaan informasi publik. LONTAR: Jurnal Ilmu Komunikasi, 4(3).

Suryani, D. A., \& Saharuddin, E. (2021). Percepatan Reformasi Birokrasi Melalui Budaya Keterbukaan Informasi di Daerah Istimewa Yogyakarta. Jurnal Ilmu Administrasi Negara ASIAN (Asosiasi Ilmuwan Administrasi Negara), 9(1), 162-175.

Syam, F. (2015). Hak Atas Informasi Dan Legal Standing Para Pihak Dalam Sengketa Informasi Di Komisi Informasi. INOVATIF| Jurnal Ilmu Hukum, 8(1). 